\title{
Microscophy Identification of Toxocara cati First Stage Larvae and Second Stage Larvae
}

\author{
Identifikasi Larva Stadium Pertama (L1) dan Larva Stadium kedua (L2) Toxocara cati \\ Secara Mikroskopis \\ ${ }^{1)}$ Eny Coolfina Simarmata, ${ }^{2)}$ Kusnoto, ${ }^{3)}$ Mochamad Lazuardi, ${ }^{2)}$ Setiawan Koesdarto, ${ }^{2)}$ Endang \\ Supriharti, ${ }^{3}$ Kuncoro Puguh Santoso \\ 1) Student, Faculty of Veterinary Medicine, Universitas Airlangga. \\ ${ }^{2}$ Department of Veterinary Parasitology, Faculty of Veterinary Medicine, Universitas Airlangga. \\ 3)Department of Basic Veterinary Medicine, Faculty of Veterinary Medicine, Universitas Airlangga. \\ Received : 14-02-2019, Accepted : 20-02-2019, Published Online : 18-06-2019
}

\begin{abstract}
This study was aimed to identify the ultra structural morphology of Toxocara cati First Stage Larvae and Second Stage Larvae using Light Microscope. Toxocara cati larvae were obtained from adult worm eggs then were treated in phospat buffer saline with comparasion $1: 1$ until it reached the stage of larvae 1 and 2 . The shell of egg Toxocara cati were thick and usually consist of three layers. The first layer was inner membrane, the second layer was middle layer and the third was outer layer. The results of larvae morphology that were identified using light microscope showed that the anterior part of Toxocara cati first stage larvae has a dorsal lip and esophagus and intestine on the posterior part but it could not be identified perfectly. The anterior part of Toxocara cati second stage larvae that were identified has three lips that leads directly into the oesophagus. Three lips on the anterior part of Toxocara cati larvae 2 consist of a dorsal lip and two subventral lips. Morphological of Toxocara cati larvae similar with the Toxocara cati adult worms because morphology of larvae and adult stage was difficult to differentiated.
\end{abstract}

Keywords : Toxocara cati, microscophy, morphology, larvae 1, larvae 2

\section{Pendahuluan}

Toksokariasis adalah penyakit parasiter yang umumnya ditemukan pada anjing (Toxocara canis) dan kucing (Toxocara cati) (Azizi et al., 2014). Infeksi cacing Toxocara spp. Terdapat dalam dua bentuk, yaitu bentuk cacing dewasa dan larva stadium kedua (L2) (Kusnoto dkk., 2016). Larva Toxocara cati memiliki ukuran yang sangat kecil dan tidak dapat dipandang secara kasat mata. Larva Toxocara cati dapat diidentifikasi dengan bantuan alat yaitu mikroskop cahaya. Mikroskop cahaya dapat memperbesar secara efektif sampai dengan 1000 kali dari ukuran asli specimen (Widyatmoko, 2008). Penggunaan mikroskop tidak hanya tergantung pada kemampuan pembesaran, tetapi lebih penting tergantung pada kemampuan untuk menguraikan dan menjelaskan hal-hal kecil (Eka dkk., 2013). Identifikasi secara spesifik larva Toxocara cati menggunakan mikroskop cahaya masih jarang dilakukan.

Siklus hidup Toxocara cati hanya dapat berlangsung secara sempurna di tubuh kucing. Larva tidak dapat berkembang menjadi dewasa jika berada didalam tubuh hospes paratenik termasuk manusia (Miyazaki, 1991 ; Corry dkk., 2016). Larva akan bermigrasi dan menimbulkan lesi dan kerusakan jaringan (Borji et al., 2011 ; Corry dkk., 2016). Cacing T.cati dalam hidupnya mengalami beberapa generasi, yakni stadium telur, larva stadium pertama (L1), kedua (L2), ketiga (L3), keempat (L4) dan cacing dewasa. Adanya perbedaan struktur morfologi pada berbagai generasi (Warren, 1993 ; Andry, 2004) mendorong penulis untuk melakukan identifikasi larva stadium pertama dan larva stadium kedua secara mikroskopis.

Morfologi larva Toxocara cati masih belum diteliti secara spesifik menggunakan mikroskop cahaya. Mikroskop cahaya memiliki resolusi 200 nm dengan pembesaran mencapai 400 - 1000 kali. Dalam penelitian ini diharapkan dapat mengidentifikasi organ larva stadium pertama dan kedua secara mikroskopis. 


\section{Materi dan Metode Penelitian Tempat dan Waktu Penelitian}

Penelitian ini dilakukan di Laboratorium Parasitologi Fakultas Kedokteran Hewan Universitas Airlangga pada bulan Januari sampai April 2018.

\section{Alat dan Bahan}

Bahan yang digunakan dalam penelitian ini antara lain cacing dewasa Toxocara cati; larva stadium pertama (L1) Toxocara cati; larva stadium kedua $\left(\mathrm{L}_{2}\right)$ Toxocara cati; larutan phospat buffer saline (PBS) untuk mengawetkan cacing sekaligus menjadi media pembiakan telur cacing menjadi larva; formalin $0,5-1 \%$ untuk membunuh mikroorganisme lain.

Alat-alat yang digunakan selama penelitian ini adalah cawan petri sebagai wadah telur dan larva, micropipette untuk pengambilan sampel, mikroskop untuk mengidentifikasi partumbuhan telur hingga menjadi larva, pinset, scalpel untuk melakukan pembedahan cacing dewasa, sentrifus untuk mengeluarkan larva dari cangkang telurnya.

\section{Prosedur Penelitian}

Jenis penelitian ini adalah Eksploratif Laboratorik. Sebanyak 3 ekor kucing penderita toksokariasis dari pasar di Surabaya diambil dan dilakukan pengobatan dengan menggunakan anti helmintika secara oral. Anti helmintika yang digunakan adalah Piperazine dalam dosis rendah. Dalam beberapa waktu, kucing tersebut mengeluarkan Toxocara cati dewasa yang tercampur dalam feses. Kemudian Toxocara cati diisolasi dalam larutan PBS sebagai media perkembang-biakan.

Setiap hari media diganti secara berkala dan cacing yang telah mati langsung dibedah untuk mendapatkan telurnya. Telur Toxocara cati dipisahkan dalam cawan petri lain dan diberi larutan PBS. Tambahkan formalin 0,5\% kedalam larutan media agar mikroorganisme lain mati. Telur cacing diamati di mikroskop cahaya secara berkala untuk mengamati perkembangannya.

Setelah $7-28$ hari diperoleh larva stadium 1 Toxocara cati. Larva tersebut diambil menggunakan micropipette dan dimasukkan dalam tabung sentrifus kemudian di sentrifus kecepatan rendah. Hal ini bertujuan agar larva stadium 1 keluar dari cangkang telurnya.

Setelah kurang lebih 28 hari, telah sampai pada tahap larva stadium kedua. Larva tersebut diambil menggunakan micropipette dan dimasukkan dalam tabung sentrifus kemudian di sentrifus kecepatan rendah. Hal ini bertujuan agar larva stadium kedua keluar dari cangkang telurnya.

Hasil data berupa foto dari larva stadium 1 dan 2 Toxocara cati. Setelah itu dilakukan identifikasi perbedaan antara larva stadium 1 dan larva stadium 2 Toxocara cati.

\section{Hasil dan Pembahasan}

Hasil identifikasi larva stadium pertama (L1) Toxocara cati menggunakan mikroskop cahaya pada bagian anterior terlihat adanya bibir yang belum terbentuk sempurna, dimana bibir ini langsung terhubung dengan oesophagus namun belum terbentuk sempurna.

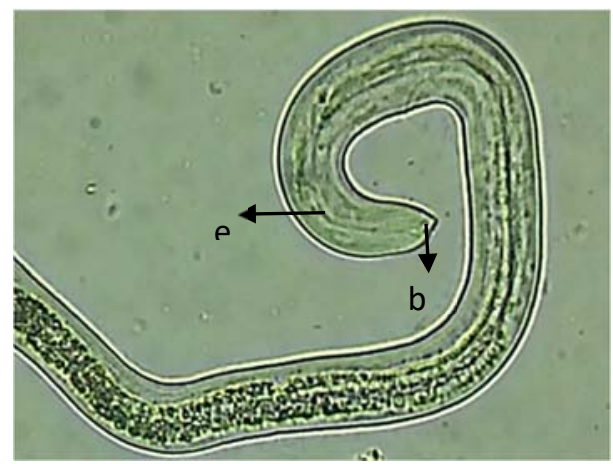

Gambar 1. Larva stadium pertama (L1) Toxocara cati bagian anterior pembesaran 40ox dan dibesarkan 4x. es = oesophagus, $\mathrm{b}=$ bibir.

Hasil identifikasi larva stadium pertama (L1) Toxocara cati menggunakan mikroskop cahaya pada bagian posterior terlihat adanya ekor yang telah terbentuk sempurna namun sistem pencernaan yang belum berbatas jelas.

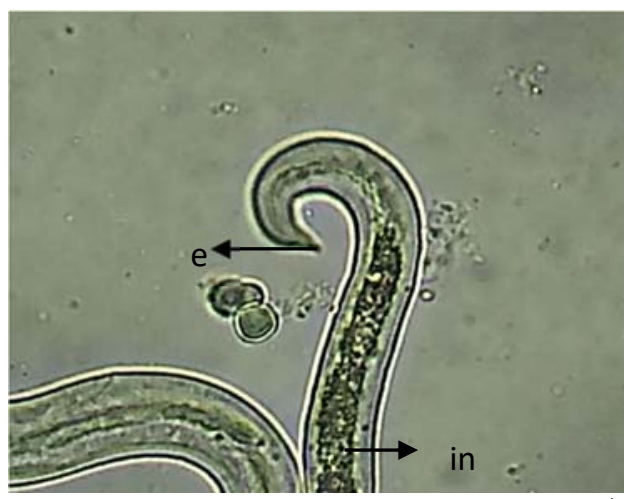

Gambar 2. Larva stadium pertama (L1) Toxocara cati bagian posterior pembesaran $400 x$ dan dibesarkan $4 \mathrm{x} . \mathrm{e}=\mathrm{ekor}$, in = intestine. 
Hasil identifikasi larva stadium kedua (L2) Toxocara cati menggunakan mikroskop cahaya pada bagian anterior terlihat booring tooth, oesophagus dan bibir yang sudah berbatas jelas dan slaing terhubung. Hal ini sesuai dengan Armour (1996) yang menyatakan bahwa mulut nematoda terdiri dari dua atau tiga bibir yang terhubung langsung dengan oesophagus.

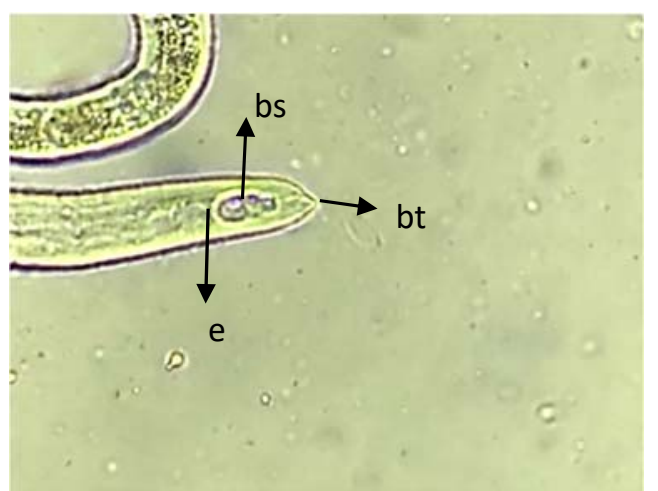

Gambar 3. Larva stadium kedua (L2) Toxocara cati bagian anterior pembesaran 400x dan dibesarkan $4 \mathrm{x}$. bs = bibir subventral, bt $=$ booring tooth, $\mathrm{e}=$ oesophagus.

Hasil identifikasi larva stadium kedua (L2) Toxocara cati menggunakan mikroskop cahaya pada bagian posterior terlihat anus yang berada pada $7 / 8$ bagian tubuh larva, sedangkan organ pencernaan dan organ reproduksi masih belum berbatas jelas. Adanya anus menunjukkan bahwa kemungkinan larva adalah betina. Keadaan ini tampaknya sesuai dengan Urquhuart (1996) yang menyatakan pada betina, akhir dari saluran pencernaan adalah anus dimana pada jantan adalah kloaka yang memiliki fungsi yang sama dengan anus dan sebagai alat reproduksi juga

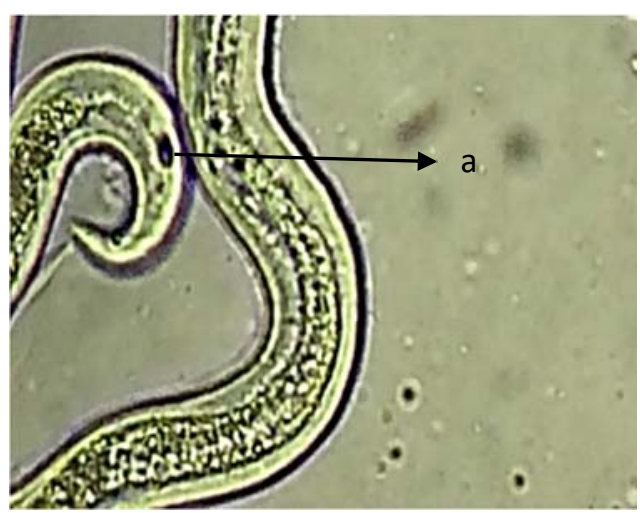

Gambar 4. Larva stadium kedua (L2) Toxocara cati bagian posterior pembesaran 400x dan dibesarkan 4X. $\mathrm{a}=$ anus.
Hasil pemeriksaan larva stadium kedua (L2) Toxocara cati menggunakan mikroskop cahaya dengan bantuan optiloab bertujuan untuk mengukur panjang dan diameter larva. Panjang rata - rata larva adalah $282.6 \mu \mathrm{m}$. Diameter rata - rata larva adalah $15.7 \mu \mathrm{m}$.

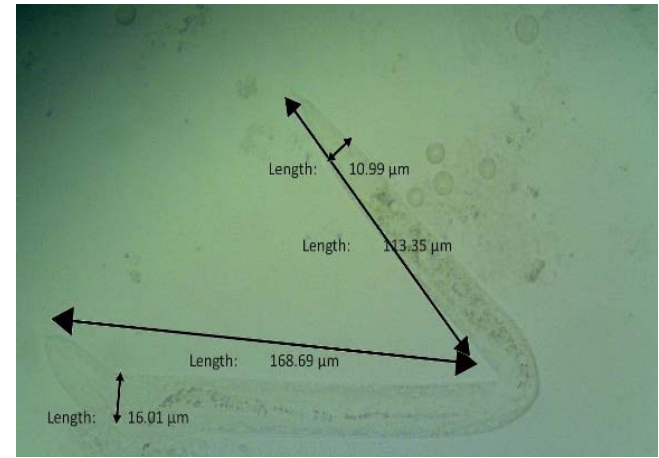

Gambar 5. Hasil pemeriksaan panjang L2 dengan mikroskop bantuan optilab.

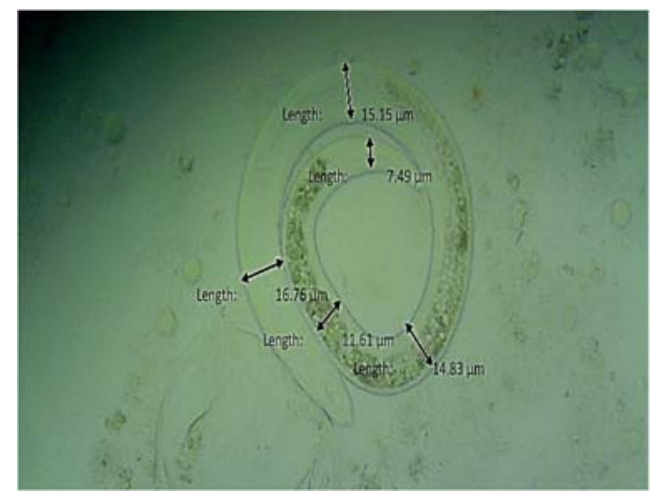

Gambar 6. Hasil pemeriksaan diameter L2 dengan mikroskop bantuan optilab.

\section{Kesimpulan}

Hasil identifikasi menggunakan mikroskop cahaya menunjukkan larva stadium pertama (Lı) memiliki bibir pada bagian dorsal, dan oesophagus pada bagian anteriornya. Pada bagian posterior, terlihat adanya intestine yang belum terbentuk sempurna. Pada bagian anterior larva stadium kedua (L2) terlihat tiga bibir yang terhubung langsung dengan oesophagus. Tiga bibir pada bagian anterior larva terdiri dari satu bibir dorsal dan dua bibir subventral. Pada bagian posterior larva stadium kedua (L2), terlihat adanya anus sebagai saluran akhir sistem pencernaan betina.

Larva stadium kedua (L2) Toxocara cati memiliki panjang tubuh antara $217.58-350.34$ $\mu \mathrm{m} \mu \mathrm{m}$ dengan rata - rata $282.6 \mu \mathrm{m}$ dan diameter dari 14,93-16.15 $\mu \mathrm{m}$ dengan rata-rata $15.7 \mu \mathrm{m}$ 


\section{Daftar Pustaka}

Andry. 2004. Identifikasi Protein Antigenik Larva Stadium Kedua (L2) Toxocara cati Dengan Teknik Western Blot. [SKRIPSI]. Fakultas Kedokteran Universitas Airlangga. Surabaya.

Armour J, JL Duncan, AM Dunn, FW Jennings, GM Urquhuart. 1996. Veterinary Parasitology. $2^{\text {nd }}$ ed. Blackwell Publishing: Veterinary Medicine of University Glasglow, Scotland. 04-07.

Azizi S, Oryan A, Sadjjadi SM, Zibaei M. 2007. Histopathological Changes and Larval Recovery of Toxocara cati in Experimentally Infected Chickens. Parasitol Res. 102: 47-52.
Borji H, Razmi G, Ahmadi A, Karami H, Yaghfoori S, Abedi N. 2011. Survey on Edoparasit and Ectoparasit of Stray Cats from Mashad (Iran) and Association with Risk Factors. J Parasit Dis. 35(1) : 202-206

Eka PH, Chairul A, Suryo K, Litta RY. 2013. Histologi Veteriner Jilid 1. Fakultas Kedokteran Hewan Universitas Airlangga. Surabaya.

Kusnoto, Rahayu E. 2016. Antigenesitas Dan Imunogenesitas Protein Spesifik Toxocara cati Untuk Pengembangan Kit Diagnostic dan Kandidat Vaksin Sub Unit. Universitas Airlangga Surabaya. 